\title{
PERAN LEMBAGA PENDIDIKAN DALAM PEMBERANTASAN TINDAK PIDANA KORUPSI DI INDONESIA
}

\author{
Ridwan \\ Fakultas Hukum Universitas Sultan Ageng Tirtayasa \\ E-mail: ridwan_untirta@yahoo.co.id
}

\begin{abstract}
Corruption act in Indonesia is a very serious crime and has serious consequences for the nation of Indonesia, and the most disadvantaged are the people, welfare of the people is the desire of every person difficult to realize, while eradication is very slow. Combating corruption is a very important part in saving the nation from the threat of destruction is therefore a serious effort is needed in its eradication. Educational institutions have an important role for the eradication of corruption in Indonesia, because of the higher education institutions by law forming the character of each person for anti-corruption can be done, for it's efforts to improve the science of divinity to be very important, so the morality of everyone, including law enforcement becomes an important part in real life can be maintained, the science of religion without science is incomplete.
\end{abstract}

Key words: corruption, moral, education, divinity

\begin{abstract}
Abstrak
Tindak pidana korupsi di Indonesia merupakan suatu kejahatan yang sangat serius dan berdampak serius bagi bangsa Indonesia, dan yang paling dirugikan adalah masyarakat, kesejahteraan rakyat yang merupakan dambaan bagi setiap orang sulit diwujudkan, sedangkan pemberantasannya sangat lamban. Pemberantasan korupsi merupakan bagian yang amat penting dalam menyelamatkan bangsa dan negara dari ancaman kehancuran oleh karenanya diperlukan upaya serius dalam pemberantasannya. Lembaga pendidikan memiliki peran yang sangat penting bagi pemberantasan korupsi di Indonesia, karena melalui lembaga pendidikan tinggi ilmu hukum pembentukan karakter setiap orang untuk anti korupsi dapat dilakukan, untuk itu upaya peningkatan ilmu ketuhanan menjadi sangat penting, sehingga moralitas setiap orang termasuk penegak hukum menjadi bagian penting dalam kehidupan nyata dapat terjaga, ilmu pengetahuan tanpa ilmu agama tidaklah lengkap.
\end{abstract}

Kata Kunci : korupsi, moral, pendidikan, ketuhanan

\section{Pendahuluan}

Negara Indonesia memiliki suatu tujuan yang mulia yaitu mendorong dan menciptakan kesejahteraan umum dalam payung Negara Kesatuan Republik Indonesia yang berlandaskan Pancasila. ${ }^{1}$ Tuj uan atau cita-cita tersebut tercermin dalam pembukaan Undang-undang Dasar Negara Republik Indonesia Tahun 1945 dalam alinea ke-4 yaitu:

"Kemudian daripada itu untuk membentuk suatu Pemerintahan Negara Indonesia yang melindungi segenap bangsa Indonesia dan seluruh tumpah darah Indone-

Ridwan, "Kebijakan Formulasi Hukum Pidana dalam Penanggulangan Tindak Pidana Korupsi", Jurnal IImiah J ure Humano, Vol. 1 No. 1, Maret 2009, Serang: Fakultas Hukum Untirta, hlm. 73. sia dan untuk memajukan kesejahteraan umum, mencerdaskan kehidupan bangsa dan ikut melaksanakan ketertiban dunia yang berdasarkan kemerdekaan, perdamaian abadi dan keadilan sosial..."

Perlindungan terhadap segenap bangsa dan tumpah darah melalui perangkat hukum yang berlaku merupakan hal yang mutlak untuk diwujudkan, tidak ada artinya kata-kata "melindungi segenap bangsa dan tumpah darah" apabila ternyata masih ada penderitaan yang dirasakan oleh rakyat berupa ketimpangan-ketimpangan hak-hak ekonomi yang mencerminkan ketidaksejahteraan bagi seluruh rakyat Indonesia. Ketidaksejahteraan tersebut didorong dan diciptakan oleh sistem pemerintahan 
yang tidak berkeadilan sosial bagi seluruh rakyat Indonesia, karena masih membiarkan adanya praktik-praktik pemerintahan di mana kekuasaan dijalankan secara sewenang-wenang dan tidak berpihak pada rakyat. ${ }^{2}$

Pemerintah oleh karena itu mempunyai peran penting dalam sebuah negara modern di mana pemerintah harus mampu menjadi lokomotif bagi perlindungan dan kesejahteraan bagi rakyatnya. Friedman menegaskan bahwa negara atau pemerintah seharusnya mampu menjalankan fungsinya sebagai negara modern, yaitu: as protector; as diooser of social services; as industrial manager; as economic controller; as arbitrator. $^{3}$

Negara sebagai lokomomotif perlindungan dan kesejahteraan bagi rakyat, menurut Melkias Hetharia: ${ }^{4}$

"Dalam sebuah negara demokrasi, hak tersebut menuntut kepada mereka yang berkuasa atasnya (penguasa) untuk memenuhinya. Dengan demikian secara otomatis penguasa wajib melaksanakan pembangunan bagi kesejahteraan masyarakat manusia yang dikuasainya. Walaupun hak itu ada dengan sendirinya (secara alami) dan pemerintah wajib untuk melaksanakannya."

Perlindungan terhadap segenap bangsa Indonesia dan seluruh tumpah darah Indonesia dapat pula berati upaya keras dan nyata bagi pembebasan seluruh rakyat Indonesia dari penderitaan dan upaya yang nyata bagi terciptanya kesejahteraan rakyat Indonesia tanpa kecuali. Namun demikian, dalam penegakan hukum pidana akhir-akhir ini menyisakan tanda tanya besar dari berbagai kalangan masyarakat termasuk pelaku, hal ini disebabkan karena adanya disparitas yang sangat mencolok dalam penerapan hukum pidana melalui lembaga peradilan, baik dalam tahapan penyidikan, penun-

\footnotetext{
Ibid. hlm. 74.

Wagiati Soetedjo," Perlindungan Hukum Terhadap A-nak dalam Hukum Pidana di Indonesia", Jurnal IImiah Litigasi, Vol. 10 No. 2, J uni 2009, Bandung: Faklutas Hukum Unpas, hlm. 181.

Melkias Hetharia, "Kebijkan Afirmatif dalam Implementasi Otonomi Khusus di Papua Berdasarkan UUD 1945", Jurnal Litigasi, Vol. 11 No. 2, Oktober 2010, Bandung: Fakultas Hukum Unpas, hlm. 617.
}

tutan maupun dalam tahap eksekusi. ${ }^{5}$ Persoalan ini berdampak pada kegagalan pemerintah dalam memenuhi hak konstitusional rakyat Indonesia.

Salah satu kegagalan pemerintah dalam memenuhi hak konstitusional rakyat Indonesia berupa kesejahteraan adalah tingginya korupsi yang kemudian melahirkan ketidaksejahteraan bagi masyarakat, korupsi yang telah meluas dan berakar di Indonesia telah menghancurkan harapan bangsa atas mimpi kesejahteraan yang selalu didambakan, bahkan mengancam eksistensi negara yang seharusnya mewujudkan mimpi kesejahteraan tersebut. Menurut Nyoman Serikat Putra J aya: ${ }^{6}$
"Tindak pidana korupsi, kolusi dan nepo- tisme tidak hanya dilakukan oleh Penye- lenggara negara, antar penyelenggara negara, melainkan juga penyelenggara negara dengan pihak lain seperti keluar- ga, kroni dan para pengusaha, sehingga merusak sendi-sendi kehidupan berma- syarakat, berbangsa, dan bernegara, ser- ta membahayakan eksistensi negara."

Sejalan dengan apa yang katakan Nyoman Serikat Putra J aya tersebut, menurut Marzuki Darusman bahwa, Penyebaran Korupsi, Kolusi dan Nepotisme sudah sangat meluas sehingga dapat dikatakan radikal korup. ${ }^{7}$

Pernyataan Marzuki Darusman, tampak berbanding lurus dengan apa data yang disaj ikan oleh Fauzi, di mana sejak tahun 2005 Bupati yang menjadi tersangka sebanyak 150 orang dari jumlah total Kepala Daerah sebanyak 524 orang. ${ }^{8}$ kondisi ini tentu sangat memprihatinkan dan memperkukuh bahwa tingkat korupsi di Indonesia memang telah memasuki area radikal korup.

Tingginya tingkat korupsi yang kemudian memasuki tingkat radikal korup, pada hakikat-

5 Ridwan, "Pembaharuan Hukum Pidana dalam Kerangka Hukum yang Berkeadilan Berdasarkan Kultur Hukum Indonesia", J urnal IImiah Media Hukum, Vol. 18 No. I, J uni 2011, Yogyakarta: Fakultas Hukum UMY, hIm. 107.

6 Ridwan, "Kebijakan...", op.cit. hlm. 75.

77 Ibid.

8 Martha Pigome, "Reformasi Sistem Penegakan Hukum dalam Mengatasi Mafia Pertambangan Mineral dan Ba-tu Bara", Jurnal Media Hukum, Vol. 18 No. 1, J uni 2011, Yogyakarta: Fakultas Hukum UMY, hIm. 136. 
nya telah menempatkan bangsa Indonesia pa-da titik keprihatinan karena tindak pidana ko-rupsi merupakan perbuatan yang bukan saja dapat merugikan keuangan negara akan tetapi juga dapat menimbulkan kerugian-kerugian pada perekonomian rakyat. Oleh karena itu, sebagai bangsa yang memiliki semangat untuk menciptakan kemakmuran secara merata dan adil, sudah semestinya Bangsa Indonesia mampu untuk mengenali dan menghindari setiap bentuk korupsi yang hanya akan dapat menciptakan kesengsaraan bagi segenap rakyat Indonesia.

Shed Husen Alatas sebagaimana yang dikutip oleh Nyoman Serikat Putra Jaya telah membaginya dalam 7 tipologi korupsi, yaitu: pertama, korupsi transaktif (transactive corruption). Di sini menunjukan kepada adanya kesepakatan timbal balik antara pihak pemberi dan pihak penerima demi keuntungan kedua belah pihak dan dengan aktif diusahakan tercapainya keuntungan oleh kedua-duanya; kedua, korupsi yang memeras (extortive corruption) adalah jenis korupsi di mana pihak pemberi dipaksa untuk menyuap guna mencegah kerugian yang sedang mengancam dirinya, kepentingannya, atau orang-orang dan hal-hal yang dihargainya; ketiga, korupsi investif (investive corruption) adalah perilaku korban korupsi dengan pemerasan. Korupsinya adalah dalam rangka mempertahankan diri, seperti pemberian barang atau jasa tanpa ada pertalian langsung dengan keuntungan tertentu, selain keuntungan yang dibayangkan akan diperoleh di masa yang akan datang; keempat, korupsi perkerabatan (nepotistic corruption) adalah penunjukan yang tidak sah terhadap teman atau sanak saudara untuk memegang jabatan dalam pemerintahan, atau tindakan yang memberikan perlakuan yang mengutamakan dalam bentuk uang atau bentuk-bentuk lain, kepada mereka, secara bertentangan dengan norma dan peraturan yang berlaku; kelima, korupsi defensif (defensive corruption) di sini pemberi tidak bersalah tetapi si penerima yang bersalah. Misal: seorang pengusaha yang kejam menginginkan hak milik seseorang, tidak berdosalah memberikan kepada penguasa tersebut sebagian dari harta itu untuk menyelamatkan harta selebihnya; keenam, ko- rupsi otogenik (autogenic corruption) suatu bentuk korupsi yang tidak melibatkan orang lain dan pelakunya hanya seorang diri; dan ketujuh, korupsi dukungan (supportive corruption) di sini tidak langsung menyangkut uang atau imbalan dalam bentuk lain. Tindakan-tindakan yang dilakukan adalah untuk melindungi dan memperkuat korupsi yang sudah ada. ${ }^{9}$

Bentuk-bentuk korupsi, terutama dalam lingkup suap merupakan penyakit yang sangat akut bagi bangsa Indonesia, karena hampir di setiap lembaga pelayanan publik (termasuk pada dunia pendidikan) suap sudah menjadi hal yang biasa, yang pada akhirnya ada kesulitankesulitan dalam mendeteksi korupsi, sehingga pencegahannya pun makin sulit dilakukan, sehingga korupsi terus berkembang dan menjalar dalam setiap aspek kehidupaan. Perlu kiranya diperhatikan dan direnungkan apa yang dikatakan oleh Habib-ur-Rahman Khan sebagaimana dikutip oleh Barda Nawawi Arief bahwa, dunia modern sepenuhnya menyadari akan problema yang akut ini. Orang demikian sibuk melakukan penelitian, seminar, konferensi internasional dan menulis buku untuk mencoba memahami masalah kejahatan dan sebab-sebabnya, agar dapat mengendalikannya, tetapi hasil bersih dari semua usaha ini adalah sebaliknya. Kejahatan bergerak terus. ${ }^{10}$

Korupsi sebagaimana kejahatan yang dikatakan oleh Habib-ur-Rahman Khan tersebut, merupakan suatu perbuatan jahat yang dilakukan oleh seseorang dalam meraih keuntungan secara tidak halal, seolah-olah tidak pernah berhenti dan habis untuk dibicarakan baik dalam forum ilmiah maupun oleh setiap masyarakat setiap hari, tetapi hasil nyatanya adalah perbuatan jahat ini terus bergerak tiada henti menggerogoti setiap sendi kehi-dupan yang dapat berpengaruh negatif bagi kehidupan masyarakat, bangsa dan negara.

Perkembangan korupsi di Indonesia masih tergolong tinggi, sementara pemberantasannya masih sangat lamban, Romli Atmasasmita, menyatakan bahwa, Korupsi di Indonesia sudah

\footnotetext{
Ridwan, “Kebijakan...", op. cit., hlm. 75-76.

Barda Nawawi Arief dalam Ridwan, "Kebijakan...", op.cit., hlm. 76.
} 
merupakan virus flu yang menyebar ke seluruh tubuh pemerintahan sejak tahun 1960-an langkah-langkah pemberantasannya pun masih tersendat-sendat sampai sekarang. ${ }^{11}$ Lebih lanjut dikatakannya bahwa korupsi berkaitan pula dengan kekuasaan karena dengan kekuasaan itu penguasa dapat menyalahgunakan kekuasaannya untuk kepentingan pribadi, keluar dan kroninya. ${ }^{12}$

Sependapat dengan Romli Atmasasmita tersebut, Nyoman Serikat Putra J aya menjelaskan bahwa harus diakui, dewasa ini Indonesia sesuai dengan hasil penelitian yang dilakukan oleh Transparancy International dan Political and Economic Risk Consultancy yang berkedudukan di Hongkong, selalu menempati kedudukan yang rawan sepanjang menyangkut korupsi. Korupsi di Indonesia harus diakui sudah bersifat sistemik dan endemik, sehingga tidak hanya merugikan keuangan negara, tetapi juga melanggar hak-hak sosial dan ekonomi masyarakat secara luas. ${ }^{13}$ Lebih lanjut dikatakan oleh Nyoman Serikat Putra Jaya, korupsi di Indonesia sudah merembes ke segala aspek kehidupan, kesemua sektor dan segala tingkatan, baik di pusat maupun daerah, penyebabnya adalah korupsi yang terjadi sejak puluhan tahun lalu dibiarkan saja berlangsung tanpa diambil tindakan yang memadai dari kaca mata hukum. ${ }^{14}$

Korupsi, apabila dibiarkan terus, maka akan menempatkan rakyat pada posisi yang sangat dirugikan, Robert Klitgaard merinci beberapa hal akibat korupsi. Pertama, suap menyebabkan dana untuk pembangunan rumah murah jatuh ke tangan yang tidak berhak; kedua, komisi untuk para penanggung jawab pengadaan barang dan jasa bagi pemerintah daerah berarti bahwa kontrak jatuh ke tangan perusahaan yang tidak memenuhi syarat; ketiga, kepolisian sering kali karena telah disuap pura-pura tidak tahu bila ada tindak pidana yang seharusnya diusutnya; keempat, pegawai pemerintah daerah

11 Romli Atmasasmita, 2004, Sekitar Masalah Korupsi, Aspek Nasional dan Aspek Internasional, Bandung: Mandar Maju, hlm. 1.

12 Ibid.

13 Nyoman Serikat Putra Jaya, 2008, Beberapa Pemikiran ke Arah Pengembangan Hukum Pidana, Bandung: Citra Aditya Bakti, hlm. 57.

14 Ibid. menggunakan sarana masyarakat untuk kepentingan pribadi; kelima, dalam rangka mendapatkan surat izin dan lisensi, warga masyarakat harus memberi uang pelicin kepada petugas bahkan kadang-kadang harus memberi suap agar surat izin atau lisensi bisa terbit; keenam, pemberian suap mengakibatkan warga masyarakat bisa berbuat sekehendak hati melanggar peraturan keselamatan kerja, peraturan kesehatan, atau peraturan lainnya sehingga menimbulkan bahaya bagi anggota masyarakat selebihnya; ketujuh, layanan pemerintah daerah diberikan hanya bila warga telah membayar sejumlah uang tambahan di luar biaya yang resmi; kedelapan, keputusan mengenai peruntukan lahan dalam kota sering dipengaruhi oleh korupsi; dan kesembilan, petugas pajak memeras warga, atau lebih bersekongkol dengan wajib pajak, memberikan keringanan pajak pada wajib pajak dengan imbalan suap. ${ }^{15}$

Melihat akibat korupsi yang demikian seriusnya, perlu dilakukan langkah-langkah pemberantasan korupsi, langkah tersebut tentu bukan hanya pada sektor penindakan tetapi juga pada sektor pencegahan yang harus melibatkan dunia pendidikan, dengan demikian pemberantasan korupsi diharapkan dapat berjalan efektif. Keterlibatan dunia pendidikan (fakultas-fakultas hukum) demikian penting, sebab melalui dunia pendidikan inilah setiap calon penegak hukum ditempa, dibekali ilmu yang cukup untuk kemudian menegakkan hukum tersebut dengan baik dan jauh dari perilaku-perilaku korup. Melalui pembekalan ilmu yang baik, diharapkan para penegak hukum tidak melakukan tindakan koruptif ketika mereka memeriksa kasus-kasus korupsi yang mereka tangani. Berkaitan dengan hal tersebut, Hilton Tarnama Putra menyatakan dengan keberadaan dan karakter dari ilmu hukum akan mempengaruhi bentuk dan cara pendidikan (tinggi) hukum yang pada gilirannya akan mempengaruhi pula

15 Robert Klitgaard (alih bahasa oleh Masri Maris), 2005, Penuntun Pemberantasan Korupsi dalam Pemerintah-an Daerah, J akarta:Yayasan Obor Indonesia, hlm. 1-2. 
cara berfikir serta berkarya para ahli hukum yang dihasilkannya. ${ }^{16}$

Bertitik tolak pada latar belakang yang dikemukakan di atas, maka permasalahan pokok dalam tulisan ini adalah berkisar pada dua masalah pokok yaitu Bagaimana peran dunia pendidikan tinggi ilmu hukum bagi terciptanya pemberantasan korupsi di Indonesia dan Aspek terpenting apa yang harus digali oleh dunia pendidikan tinggi ilmu hukum bagi pemberantasan tindak pidana korupsi yang efektif?

\section{Peran Dunia Pendidikan bagi Terciptanya Pemberantasan Korupsi di Indonesia}

Dunia pendidikan yang menyelenggarakan pendidikan tentang ilmu hukum sesungguhnya memiliki peran yang sangat strategis dalam pemberantasan tindak pidana korupsi, bahkan kegagalan sebuah pemberantasan tindak pidana korupsi dapat dikatakan sebagai kegagalan dunia pendidikan tinggi ilmu hukum, mengapa demikian? karena dipandang dari kaca mata penegakan hukum (hukum pidana), maka penegakan hukum pidana tak terlepas dari sistem dan dalam sistem penegakan hukum terdiri dari tiga sub sistem, yaitu substansi hukum, struktur hukum dan kultur hukum. Menurut Lawrence $M$. Friedman, kultur merupakan komponen yang sangat penting dan menentukan bekerjanya sistem hukum, di mana kultur hukum tersebut merupakan elemen sikap dan nilai sosial. ${ }^{17}$

Termasuk dalam kultur hukum ini adalah pendidikan yang dapat membentuk karakter seseorang termasuk penegak hukum, dengan demikian para penegak hukum (hukum pidana) tidak terjebak pada pemikiran hukum yang sempit yang hanya memahami hukum hanya sekedar teks undang-undang. Melalui pendidikan yang baik diharapkan pula setiap penegak hukum (hukum pidana) memiliki pemahaman hukum yang baik pula, sehingga dengan pema-haman hukum yang baik akan menciptakan pe-

16 Hilton Tarnama Putra, "Ontologi IImu Hukum (suatu Tinjauan dari Perspektif Filsafat IImu)", J urnal Jure Humano, Vol. 1 No. 3, November 2009, Serang: Fakultas Hukum Untirta, hlm. 35.

17 Ridwan, "Upaya Memperbaharui Sistem Hukum Guna Membangun Integritas Penegak Hukum", Jurnal Konstitusi PKK FH. Unram, Vol. II No.1, J uni 2011, Lombok: FH Unram, hlm. 31. negak-penegak hukum yang handal. Menurut Barda Nawawi Arief, peningkatan kualitas SDM penegak hukum akan menciptakan penegak hukum yang bersih dan berwibawa, yang jujur dan bermoral, tidak korup dan dapat dipercaya menegakkan nilai-nilai kebenaran dan keadilan, ${ }^{18}$ peningkatan kualitas pendidikan akan menciptakan penegak-penegak hukum yang al-amin (dapat dipercaya), karena tidak hanya sekedar memahami hukum homo juridicus, tetapi juga memiliki etika/moral atau yang disebut dengan "homo etichus". ${ }^{19}$ Oleh karena itu, menegakkan wibawa hukum pada hakikat-nya menegakan nilai kepercayaan di dalam masyarakat.

Menegakkan wibawa hukum, berarti pula menegakkan fungsi dari hukum pidana yang pada inti hakikatnya fungsi dari hukum pidana adalah penyelesaian konflik. Hal mana ditegaskan oleh G. Peter Hoefnagles bahwa fungsi dari hukum pidana adalah penyelesaian konflik. ${ }^{20}$

Penerapan hukum pidana dengan penekanan, bahwa hukum pidana berfungsi bagi penyelesaian konflik, tentu juga harus didukung oleh kemampuan seorang penegak hukum dalam memahami dan menganalisa teori-teori hukum pidana yang dapat dijadikan sebagai sebuah landasan dan hal itu mustahil dapat ditemukan, jika karakter keilmuan seorang penegak hukum masih tergolong lemah yang pada akhirnya akan menciptakan ketidakmampuan bagi seorang penegak hukum pidana melakukan terobosan guna terciptanya penegakan hukum pidana yang berkeadilan. Karakter keilmuan yang kuat juga akan memperteguh karakter seorang penegak hukum pidana untuk selalu mengarahkan hukum dalam pemenuhan perlindungan hukum bagi setiap masyarakat tanpa sebuah kekecualian.

Semua pembentukan perilaku penegak hukum (hukum pidana) tersebut akan terben-

18 Ridwan, "Telaah Kritis Tentang Penerapan Hukum Represif dalam Penegakan Hukum Pidana di Indonesia", J urnal Litigasi, Vol. 11 No. 2, Oktober 2010, Bandung: Fakultas Hukum Unpas, hlm. 663.

19 Ridwan, "Upaya Memperbaharui...", op. cit., hlm. 36.

20 Langgeng Purnomo, "Kesepakatan Sosial Sebagai Upaya Pencegahan dan Penanggulangan Tindak Pidana Pemilu (Studi Kasus Konflik Pemilu Tahun 2004 di Kabupaten Batang)", J urnal Law Reform, Vol. 3 No. 1, Februari 2007, Semarang: Program Magister IImu Hukum Undip, hlm. 12 
tuk mana kala dunia pendidikan yang menyelenggarakan pendidikan ilmu hukum juga menunjukkan karakternya yang baik, sebagai sebuah lembaga pendidikan yang jauh dari bentuk tindakan yang koruptif termasuk di dalam pratik perbuatan curang dan perilaku yang mau disuap, tetapi mencerminkan sebuah perilaku jujur yang menunjukkan martabatnya yang tinggi. Salah satu bentuk korupsi di dunia pendidikan yang harus dihindari adalah tenaga pendidik/pengajar yang dengan sengaja dan dengan alasan yang tidak dibenarkan oleh hukum (alasan yang bisa diterima oleh hukum misalnya karena sakit, penelitian, seminar dan tugas negara lainnya serta bencana alam) kemudian meninggalkan tugas pokoknya yaitu mengajar.

Melalui pengembangan perilaku yang baik dan harus diajarkan, serta dipraktikan, terutama diperguruan tinggi yang mengajarkan tentang ilmu hukum, maka pemberantasan tindak pidana korupsi akan dapat diwujudkan secara baik. Hal ini disebabkan, melalui lembaga pendidikan ilmu hukum para penegak hukum (hukum pidana) yang merupakan bagian dari sistem penegakan hukum pidana (struktur hukum) itu dibentuk dan dibekali ilmu yang baik.

Pembekalan ilmu yang baik, tentu akan menimbulkan dampak yang positif bagi terciptanya iklim penegakan hukum pidana yang selalu berorientasi pada kepentingan hukum yang luas, yakni menyangkut kepentingan hukum secara individu maupun kelembagaan (kepentingan umum), sehingga dengan demikian setiap penegak hukum pidana menyadari bahwa hukum pidana tidak hanya mengatur per-buatan manusia, tetapi juga mengatur penegak hukum itu sendiri. Barda Nawawi Arief menjelaskan bahwa sasaran/adresat dari hukum pidana tidak hanya mengatur perbuatan warga masyarakat pada umumnya, tetapi juga mengatur perbuatan (dalam arti kewenangan/ kekuasaan) penguasa/aparat penegak hukum ${ }^{21}$ dan dengan memahami pembatasan/pengaturan oleh hukum pidana tersebut, para penegak hukum pi-

21 Barda Nawawi Arief dalam Ridwan, “Upaya Penanggulangan Kejahatan Terorisme yang Berkarateristik Hak Asasi Manusia di Indonesia", Jurnal IImiah Media Hukum, Vol. 17 No. 1, J uni 2010, Yogyakarta: Fakultas Hukum UMY, hlm. 182. dana akan mampu menjadi corong kebenaran, bukan sekedar corong undang-undang.

\section{Penggalian Aspek Pendidikan bagi Pemberan- tasan Tindak Pidana Korupsi yang Efektif}

Pada hakikatnya korupsi merupakan sebuah persoalan tentang moralitas, bagi seseorang yang memiliki tingkat moralitas yang baik tidak akan melakukan tindakan tak terpuji (korupsi). Oleh karena itu, pendidikan moralitas sangat diperlukan dalam membentuk pribadi yang baik.

Pendidikan moralitas tak dapat dipisahkan dari pendidikan agama yang merupakan ilmu tentang ketuhanan, menurut Moeljatno bahwa ilmu pengetahuan (termasuk ilmu hukum, pen.) yang tidak dibarengi dengan ilmu ketuhanan adalah tidak lengkap. ${ }^{22}$ Begitu eratnya hubungan antara ilmu pengetahuan hukum dengan ilmu ketuhanan, Satjipto Rahardjo mengungkapkannya dengan sangat indah sekali bahwa, ilmu adalah forum untuk berburu kebenaran yang tidak akan bisa digenggamnya secara sempurna. Otak kecil manusia hanya bisa menemukan keping-keping kebenaran, sedangkan kebenaran sejati hanya milik Allah. Di sini ilmu pengetahuan dan religi bertemu. ${ }^{23}$

Mendasarkan pada kekuatan besar antara ilmu pengetahuan sebagai sarana memburu kebenaran yang besifat relatif, di mana kebenaran yang demikian sebagaimana yang dikatakan Satjipto Rahardjo adalah kebenaran yang tak mungkin secara sempurna dapat digenggam, sehingga guna menggenggam kebenaran diperlukan kekuatan besar lainnya yaitu kebenaran hakiki yang dimiliki Tuhan, dengan demikian, maka sekat-sekat ketidakharmonisan antara hukum dan keadilan akan dapat diatasi, sehingga masyarakat akan mampu merasakan hukum yang mampu menaungi kehidupannya ketika hukum itu ditegakkan. Sebaliknya, jika ilmu pengetahuan hukum dan ilmu ketuhanan dilepaspisahkan, maka akan terjadi persoalanpersoalan yang sangat mendasar bagi negara Indonesia, karena hukum akan ditegakkan dengan

\footnotetext{
22 Moeljatno dalam Ridwan, "Upaya Memperbaharui..." Op.cit., hlm. 36.

23 Ibid.
} 
pola-pola koruptif yang dapat mendorong runtuhnya Indonesia sebagai sebuah bangsa.

Runtuhnya sebuah bangsa yang diakibatkan oleh tingkat korupsi yang demikian akut, sesungguhnya dimulai dari dunia pendidikan tinggi ilmu hukum yang tidak lagi memiliki konsentrasi dan porsi yang cukup bagi pendidikan ilmu ketuhanan, yang pada akhirnya melahirkan perilaku-perilaku munafik dan tidak raguragu menjadi bagian dari suburnya perilaku koruptif. Berkaitan dengan ilmu Ketuhanan yang berisikan tuntunan Tuhan tersebut, oleh Purnadi Purbacaraka disebutnya sebagai kaidah kepercayaan, dengan kaidah tersebut bertujuan mencapai suatu kehidupan yang beriman, ${ }^{24}$ dengan kehidupan yang beriman tersebut tentulah diharapkan tercapainya penegakan hukum yang baik jujur dan jauh dari nilai-nilai yang munafik. ${ }^{25}$ Menurut Romli Atmasasmita, hukum dan penegakan hukum berada dalam ruang dinamika keimanan, kepastian hukum dan keadilan. Penegakan hukum tanpa keimanan dapat menimbulkan kemunafikan dan kezaliman. ${ }^{26}$

Pembentukan karakter melalui pendidikan moral yang merupakan unsur terpenting dari pendidikan ilmu ketuhanan tidak terlepas dari sifat ilmu hukum (termasuk hukum pidana) sebagai bagian dari ilmu kejiwaan sebagaimana yang dikatakan Barda Nawawi Arief sebagai pakar hukum pidana menyatakan bahwa aspek nilai kejiwaan ini ada dan melekat pada setiap "hukum" pada umumnya. Oleh karena itu, wajarlah ilmu hukum (termasuk ilmu hukum pidana) dikelompokkan ke dalam ilmu pengetahuan kejiwaan/ kerohanian (Geisteswissenschaft), ${ }^{27}$ bahkan menurutnya bahwa dengan demikian ilmu hukum pidana normatif pada hakikatnya bukan semata-mata ilmu tentang norma, tetapi justru ilmu tentang nilai, di mana proses penguasaan "nilai" lebih menuntut pendekatan kejiwaan/ kerohanian karena sasaran yang akan

24 Ridwan, "Peran IImu Ketuhanan dan Kultur Hukum dalam Menciptakan Putusan Hakim dan Hakim Mahkamah Konstitusi yang Berkeadilan", J urnal IImiah Mahkamah Konstitusi PKK Unram, 2 November 2011, Lombok: Fakultas Hukum Unram, hlm. 100.

25 Ibid.

26 Ridwan, "Upaya Memperbaharui...", op.cit., hlm. 36.

27 Ridwan, "Peran Ilmu...", op.cit.hlm. 101. disentuh adalah nilai-nilai kejiwaan. ${ }^{28} \mathrm{Hal}$ ini mempertegas mengenai hubungan yang demikian erat antara ilmu hukum pidana dengan kejiwaan, termasuk dalam proses penerapannya di pengadilan.

IImu hukum pidana, sebagai sebuah ilmu kejiwaan, maka dapat mempengaruhi cara berfikir dan bertindak seseorang dalam perga-ulan hidupnya sehari-hari di dalam masyarakat, sehingga seseorang dapat menentukan mana yang baik dan buruk dalam bertindak menurut hukum yang berlaku dalam masyarakat. Cara berfikir yang demikian akan terpaut erat dengan terbentuknya sebuah karakter dan memperteguh sebuah kultur yang dapat mempengaruhi tingkat kejahatan. Schultz menyatakan bahwa naik turunnya kejahatan di suatu negara tidaklah ditentukan oleh perubahan-perubahan di dalam hukumnya atau kecenderungan-kecenderungan dalam putusan-putusan pengadilan, tetapi berhubungan dengan bekerjanya atau berfungsinya perubahan-perubahan kultural yang besar dalam masyarakat. ${ }^{29}$

Berkaitan dengan apa yang dikatakan oleh Schultz tersebut, J ohanes Andeneas menyatakan, bekerjanya hukum pidana harus dilihat dari keseluruhan konteks kulturnya. Terdapat hubungan saling pengaruh-mempengaruhi antara hukum dengan faktor-faktor lain yang membentuk sikap dan tindakan kita, ${ }^{30}$ dengan demikian perlu konsep yang mampu mensinergikan antara ilmu pengetahuan hukum dengan ilmu pengetahuan tentang Ketuhanan.

Melalui konsep penegakan hukum yang memadukan ilmu pengetahuan hukum dan il-mu pengetahuan Ketuhanan inilah ef ektivitas penegakan hukum akan terwujud. Efektivitas di sini dapat berarti efek keberhasilan ${ }^{31}$ dan melalui peningkatan keilmuan yang integral itu pula diharapkan penegak hukum pidana memahami hukum dan sekaligus patuh terhadap nilai-nilai hukum. Ketaatan hukum oleh penegak hukum

28 Ibid, hlm. 52

29 Ridwan, "Relavansi Restorative Justice dalam Penanganan Anak Delinquen", J urnal J ure Humano, Vol. 1 No. 3, November 2009, Serang: Fakultas Hukum Untirta, hlm. 67.

30 Ibid.

31 Barda Nawawi Arief, 2003, Kapita Selekta Hukum Pidana, Bandung: Penerbit Citra Aditya Bakti, hlm. 85. 
tersebut tentu diharapkan sebagai wujud pencarian tiada henti atas nilai-nilai kebenaran dan keadilan, Hegel sebagai-mana yang dikutip oleh Zaenal Abidin menya-takan bahwa:

“Hidup ini teramat pendek, tapi kebenaran berlaku lama dan berumur panjang, oleh sebab itu, mari kita berbicara tentang kebenaran. ${ }^{32}$

Pendidikan yang integral akan mampu menciptakan manusia-manusia yang taat terhadap hukum, Sophocles menegaskan bahwa tiada orang yang paling memiliki kewajiban suci untuk mentaati lebih dari mereka yang pekerjaannya adalah membuat dan menjalankan hukum. ${ }^{33}$

Pemahaman hukum yang baik, sebagai suatu hasil dari proses peningkatan pendidikan dan pengetahuan mengenai ilmu pengetahuan hukum (pidana) dan ilmu ke-tuhanan Yang Maha Esa, akan menciptakan budaya yang baik yang dimiliki oleh para penegak hukum, pemahaman hukum tersebut akan menghasilkan pemikiran yang utuh bagi setiap penegak hukum, bahwa hukum bukan semata-mata hanya sebuah teks undang-undang yang sangat kaku dan hanya bekerja berlandaskan kepastian undangundang semata. Pemahaman hukum yang utuh dengan memadukan ilmu pengetahuan hukum dan ilmu ketuhanan akan menghindarkan para penegak hukum bertindak dan berbuat di luar kendali hukum, sehingga keadilan tidak lagi menjadi barang langka di negeri Indonesia tercinta ini, melainkan setiap tindakan hukum yang dilakukan oleh para penegak hukum selalu berlandaskan pada prinsip keadilan.

Perlu juga dipahami, bahwa penerapan ilmu ketuhanan di lembaga-lembaga pendidikan tinggi yang mengajarkan ilmu hukum, sesungguhnya telah memliki landasan yuridis yang sangat kuat, hal mana dirumuskan secara gamblang dalam Pembukaan Undang-undang Dasar

32 Ridwan, "Kewibawaan Hukum Melalui Proses Penegakan Hukum di Indonesia", J urnal IImiah Tadulako, Vol. 7 No. 4, Januari 2008, Sulawesi : Forum Silaturahmi Mahasiswa Pascasarjana Sulawesi Tengah se-Bandung, hlm. 3128.

33 Ridwan, "Membangun Institusi Penegak Hukum yang Profesional", J urnal IImiah jure Humano, Vol. 1 No. 2, J uli 2009, Serang: Fakultas Hukum Untirta, hlm. 86.
Negara Republik Indonesia Tahun 1945 yakni pada alinea ke empat.

Rumusan tersebut telah menempatkan Pancasila sebagai bagian yang tak terpisahkan antara kesejahteraan dan kecerdasan, di mana Pancasila merupakan asas moral yang sangat fundamental bagi bangsa Indonesia. Sila yang pertama Pancasila menurut A. Gunawan Setiardja merupakan sila yang mendasari sila sila yang lainnya, Tuhan merupakan causa prima atau realitas yang tertinggi, ${ }^{34}$ bahkan menurut Zainuddin Ali, dengan susunan sila-sila dalam Pancasila tersebut menunjukkan Pancasila sebagai dasar kerohanian negara republik Indonesia ${ }^{35}$ Pandangan bahwa Pancasila merupakan dasar kerohanian bangsa Indonesia seharusnya menjelma pada setiap tindakan penegak hukum dalam menegakkan hukum pidana, sehingga di dalam penegakan hukum tersebut tidak dilandasi oleh sikap-sikap munafik, represif dan sikap tercela lainnya, termasuk di dalamnya adalah penegakan hukum dengan menggunakan timbal balik yang dianggap saling menguntungkan yaitu jual beli perkara, yang pada prinsipnya merupakan prilaku pemerkosaan terhadap nilai-nilai keadilan dan kejujuran, yang seharusnya nilai-nilai tersebut diemban dan dikonkritkan oleh setiap penegak hukum.

Suatu hal yang sangat mustahil bagi sebuah penegakan hukum yang baik, di mana nilai luhur Pancasila yang merupakan Iandasan moral bangsa Indonesia menjadi bagian yang utuh dalam penegakan hukum pidana termasuk di dalamnya pemberantasan korupsi, jika nilainilai luhur tersebut tidak aktualisasikan dalam sebuah penyelenggaraan pendidikan melalui lembaga pendidikan tinggi yang mengajarkan ilmu hukum. Pendidikan tinggi yang mengajarkan ilmu hukum, dengan demikian harus memprioritaskan ilmu ketuhanan dalam kurikulum yang dijalankan, mengingat ilmu ketuhanan merupakan aspek yang sangat fundamental dalam membentuk mentalitas anak bangsa. Mental yang baik inilah yang diperlukan guna pemberantasan tindak pidana korupsi secara

\footnotetext{
34 Ridwan, "Pembaharuan ...", Jurnal Media Hukum, Op.cit., hlm. 113.

35 Ibid
} 
lebih efektif. Menurut Notonegoro Ketuhanan Yang Maha Esa adalah aspek utama dan mendasar dalam mengelola dan menyelenggarakan negara Indonesia. ${ }^{36}$

\section{Penutup \\ Simpulan}

Lembaga pendidikan tinggi yang mengajarkan ilmu hukum memiliki peran yang sangat sentral bagi terciptanya pemberantasan tindak pidana korupsi di Indonesia, karena lembaga ini merupakan kawah candra di muka bagi setiap orang untuk memiliki karakter yang mulia, sehingga setiap pribadi (termasuk penegak hukum pidana) memiliki mental yang baik dan tidak berperilaku koruptif. Dalam rangka menciptakan pribadi-pribadi yang memiliki mental anti korupsi, maka diperlukan pribadi-pribadi yang memiliki tingkat moralitas yang baik dan untuk membentuk moralitas yang baik, maka diperlukan aspek yang sangat penting dalam pembentukan moral tersebut yaitu ilmu ketuhanan. IImu pengetahuan tidaklah lengkap, jika tidak di barengi dengan ilmu ketuhanan. Melalui ilmu ketuhanan ini, maka setiap pribadi penegak hukum akan mampu menerapkan hukum pidana dengan baik, dengan berpatokan pada tanggung jawab terhadap manusia dan Tuhan.

\section{Saran}

Perlu dilakukan secara terus menerus perbaikan dan penyiapan moral Dalam rangka terciptanya pemberantasan tindak pidana korupsi yang efektif bagi setiap orang melalui lembaga pendidikan tinggi yang meng-ajarkan ilmu hukum. Lembaga pendidikan tinggi yang mengajarkan ilmu hukum, sebagai lembaga yang memiliki peran yang sangat penting dalam pemberantasan korupsi maka perlu membuat formulasi yang lebih baik lagi bagi kurikulum yang berbasis pada ilmu ketuhanan, sehingga dengan demikian, lembaga pendidikan tinggi yang mengajarkan ilmu hukum benar-benar menjadi kawah candradimuka bagi setiap orang

36 Firdaus, "Refleksi Filosofis Atas Pancasila sebagai Grundnorm dalam Pengembangan Sitem Hukum Nasional", J urnal IImiah Tadulako, Vol. 7 No. 4, Januari 2008, Sulawesi: Forum Silaturahmi Mahasiswa Pascasarjana Sulawesi Tengah se-Bandung, hlm. 3072. termasuk bagi para penegak hukum, sehingga penegak hukum betul-betul al-amin dalam menjalankan kepercayaan yang telah diberikan pada masyarakat, karena menegakan hukum berarti menegakkan nilai-nilai kepercayaan masyarakat.

\section{Daftar Pustaka}

Arief, Barda Nawawi. 2003. Kapita Selekta Hukum Pidana. Bandung: Penerbit Citra Aditya Bakti;

Atmasasmita, Romli. 2004. Sekitar Masalah Korupsi, Aspek Nasional dan Aspek Internasional. Bandung: Mandar Maju;

Firdaus. "Refleksi Filosofis Atas Pancasila sebagai Grundnorm dalam Pengembangan Sitem Hukum Nasional". Jurnal IImiah Tadulako. Vol. 7 No. 4. J anuari 2008. Sulawesi: Forum Silaturahmi Mahasiswa Pascasarjana Sulawesi Tengah se-Bandung;

Hetharia, Melkias. "Kebijkan Afirmatif dalam Implementasi Otonomi Khusus di Papua Berdasarkan UUD 1945", J urnal Litigasi. Vol. 11 No. 2. Oktober 2010. Bandung: Fakultas Hukum Unpas;

Jaya, Nyoman Serikat Putra. 2008. Beberapa Pemikiran ke Arah Pengembangan Hukum Pidana. Bandung: Citra Aditya Bakti;

Klitgaard, Robert. 2005. Penuntun Pemberantasan Korupsi dalam Pemerintahan Daerah. (alih bahasa oleh Masri Maris).J akarta: Yayasan Obor Indonesia;

Pigome, Martha. "Reformasi Sistem Penegakan Hukum dalam Mengatasi Mafia Pertambangan Mineral dan Batu Bara". J urnal Media Hukum. Vol. 18 No. 1, Juni 2011, Yogyakarta: Fakultas Hukum UMY;

Purnomo, Langgeng. “Kesepakatan Sosial Sebagai Upaya Pencegahan dan Penanggulangan Tindak Pidana Pemilu (Studi Kasus Konflik Pemilu Tahun 2004 di Ka-bupaten Batang)". Jurnal Law Reform. Vol. 3 No. 1. Februari 2007. Semarang: Program Magister IImu Hukum Undip;

Putra, Hilton Tarnama. "Ontologi IImu Hukum (suatu Tinjauan dari Perspektif Filsafat IImu)". J urnal J ure Humano, Vol. 1 No. 3, November 2009. Serang: Fakultas Hukum Untirta;

Ridwan. "Kewibawaan Hukum Melalui Proses Penegakan Hukum di Indonesia". Jurnal 
Ilmiah Tadulako. Vol. 7 No. 4. Januari 2008. Sulawesi: Forum Silaturahmi Mahasiswa Pascasarjana Sulawesi Tengah se-Bandung;

------. “Kebijakan Formulasi Hukum Pidana dalam Penanggulangan Tindak Pidana Korupsi". J urnal IImiah Jure Humano, Vol. 1 No. 1. Maret 2009. Serang: Fakultas Hukum Untirta;

"Membangun Institusi Penegak Hukum yang Profesional". J urnal IImiah J ure Humano. Vol. 1 No. 2. Juli 2009. Serang: Fakultas Hukum Untirta;

-.-.--. "Relavansi Restorative Justice dalam Penanganan Anak Delinquen". J urnal J ure Humano. Vol. 1 No. 3. November 2009. Serang: Fakultas Hukum Untirta;

-.---.-. “Upaya Penanggulangan Kejahatan Terorisme yang Berkarateristik Hak Asasi Manusia di Indonesia". Jurnal IImiah Media Hukum. Vol. 17 No. 1. Juni 2010. Yogyakarta: Fakultas Hukum UMY;

"Telaah Kritis Tentang Penerapan Hukum Represif dalam Penegakan Hukum Pidana di Indonesia". J urnal Litigasi. Vol.
11 No. 2. Oktober 2010. Bandung: Fakultas Hukum Unpas;

" "Pembaharuan Hukum Pidana dalam Kerangka Hukum yang Berkeadilan Berdasarkan Kultur Hukum Indonesia". J urnal IImiah Media Hukum. Vol. 18 No. I. J uni 2011. Yogyakarta: Fakultas Hukum UMY;

------, "Upaya Memperbaharui Sistem Hukum Guna Membangun Integritas Penegak Hukum". Jurnal Konstitusi PKK FH. Unram. Vol. II No.1. Juni 2011. Lombok: FH Unram;

"Peran IImu Ketuhanan dan Kultur Hukum dalam Menciptakan Putusan Hakim dan Hakim Mahkamah Konstitusi yang Berkeadilan". Jurnal IImiah Mahkamah Konstitusi PKK Unram. Vol.II No.1. November 2011. Lombok: Fakultas Hukum Unram;

Soetedjo, Wagiati. "Perlindungan Hukum Terhadap Anak dalam Hukum Pidana di Indonesia". J urnal IImiah Litigasi. Vol. 10 No. 2, J uni 2009. Bandung: Faklutas Hukum Unpas. 